UDC $624.04,519.853$

\title{
PARAMETRIC OPTIMIZATION OF STEEL STRUCTURES BASED ON GRADIENT PROJECTION METHOD
}

\author{
V.V. Yurchenko ${ }^{1}$, \\ Doctor of Technical Science, Associate Professor \\ I.D. Peleshko ${ }^{2}$, \\ Candidate of Technical Science, Associate Professor \\ ${ }^{1}$ Kyiv National University of Construction and Architecture \\ Povitroflotskyj av., 31, Kyiv, 03680 \\ ${ }^{2}$ Lviv Polytechnic National University \\ St. Bandery, 12, Lviv, 79013
}

DOI: $10.32347 / 2410-2547.2020 .105 .192-220$

The main research goal is the development of a numerical methodology for solving parametric optimization problems of steel structures with orientation on software implementation in a computer-aided design system. The paper has proposed a new mathematical model for parametric optimization problems of steel structures. The design variable vector includes geometrical parameters of the structure (node coordinates), cross-sectional dimensions of the structural members, as well as initial pre-stressing forces introduced into the specified redundant members of the structure. The system of constraints covers load-carrying capacities constraints formulated for all design sections of structural members of the steel structure subjected to all ultimate load case combinations. The displacements constraints formulated for the specified nodes of the steel structure subjected to all serviceability load case combinations have been also included into the system of constraints. The method of the objective function gradient projection onto the active constraints surface with simultaneous correction of the constraints violations has been used for solving the parametric optimization problem. A numerical algorithm for solving the formulated parametric optimization problems of steel structures has been developed in the paper. The comparison of the optimization results of truss structures presented by the paper confirms the validity of the optimum solutions obtained using the proposed numerical methodology.

Keywords: parametric optimization, steel structures, nonlinear programming, buckling constraints, pre-stressing forces, node coordinates, gradient projection method, finite element analysis, numerical algorithm.

Introduction. Over the past 50 years, numerical optimisation and finite element method have individually made significant advances and have together been developed to make possible the emergence of structural optimisation as a potential design tool. In recent years, great efforts have been also devoted to integrate optimisation procedures into the CAD facilities. With these new developments, lots of computer packages are now able to solve relatively complicated industrial design problems using different structural optimisation techniques.

Applied optimum design problems for the bar structures in some cases are formulated as parametric optimisation problems, namely as searching problems for unknown structural parameters, whose provide an extreme value of the specified purpose function in the feasible region defined by the specified 
constraints. In this case structural optimisation performs by variation of the structural parameters when the structural topology, cross-section types and node type connections of the bars, the support conditions of the bar system, as well as loading patterns and load design values are prescribed and constants. Besides, the mathematical model of the parametric optimization problem of the structures includes the set of design variables, the objective function, as well as constraints, whose reflect in general case non-linear interdependences between them [13].

In cases if the purpose function and constraints of the mathematical model are continuously differentiable functions, as well as the search space is smooth, then the parametric optimization problems are successfully solved using gradient-based non-linear methods $[14,16]$. The gradient-based methods operate with the first derivatives or gradients only both of the objective function and constraints. The methods are based on the iterative construction such sequence of the approximations of the design variables that provides the convergence to the optimum solution (optimum values of the structural parameters) $[5,6]$.

Additionally, a sensitivity analysis is a useful optional feature that could be used in scope of the numerical algorithms developed based on the gradients methods [10].

Although many papers are published on the parametric optimization of steel structures, the development of a general computer program for the design and optimization of building structures according to specified design codes remains an actual task. Therefore, the main research goal is the development of a methodology for solving parametric optimization problems of steel structures with orientation on software implementation in a computer-aided design system.

In this paper, steel structures are considered as research object, which investigated for the searching for optimum parameters of the structural form. The following research tasks are formulated: to develop a mathematical model for parametric optimization of steel structures taking into account loadcarrying capacities and stiffness constraints; to propose a numerical algorithm for parametric optimization of steel structures based on the gradient projection method; to confirm the validity of the optimum solutions obtained using the proposed methodology based on numerical examples.

\section{Problem formulation for parametric optimization of steel} structures. Let us consider a parametric optimization problem of a structure consisting of bar members. The problem statement can be performed taking into account the following assumptions widely used in structural mechanic problems: the material of the structure is ideal elastic; the bar structure is deformable linearly; external loadings applied to the structure are quasi-static.

Let us also formulate the following pre-conditions for calculation: crosssection types and dimensions of structural members are constant along member lengths; external loadings are applied to the structural members without eccentricities relating to the center of mass and shear center of its cross-sections; an additional restraining by stiffeners are provided in the design sections where point loads (reactions) applied with the exception of crosssection warping and local buckling of the cross-section elements; load-carrying capacity of the structural joints, splices and connections are provided by 
additional structural parameters do not covered by the considered parametric optimization problem.

A parametric optimization problem of the structure can be formulated as presented below: to find optimum values for geometrical parameters of the structure, member's cross-section dimensions and initial pre-stressing forces introduced into the specified redundant members of the bar system, which provide the extreme value of the determined optimality criterion and satisfy all load-carrying capacities and stiffness requirements. We assume, that the structural topology, cross-section types and node type connections of the bars, the support conditions of the bar system, as well as loading and pre-stressing patterns are prescribed and constants.

The formulated parametric optimization problem can be considered integrally using the mathematical model in the form of the non-linear programming task including an objective function, a set of independent design variables and constraints, which reflect generally non-linear dependences between them. The validity of the mathematical model can be estimated by the compliance of its structure with the design code requirements.

The parametric optimization problem of steel structures can be stated in the following mathematical terms: to find unknown structural parameters $\vec{X}=\left\{X_{l}\right\}^{T}, \imath=\overline{1, N_{X}}$, providing the least value of the determined objective function:

$$
f^{*}=f\left(\vec{X}^{*}\right)=\min _{\vec{X} \in \mathfrak{I}_{\perp}} f(\vec{X}),
$$

in a feasible region (search space) $\mathfrak{I}$ defined by the following system of constraints:

$$
\begin{gathered}
\psi(\vec{X})=\left\{\psi_{\kappa}(\vec{X})=0 \mid \kappa=\overline{1, N_{E C}}\right\}, \\
\varphi(\vec{X})=\left\{\phi_{\eta}(\vec{X}) \leq 0 \mid \eta=\overline{N_{E C}+1, N_{I C}}\right\},
\end{gathered}
$$

where $\vec{X}$ is the vector of the design variables (unknown structural parameters); $f, \psi_{\kappa}, \varphi_{\eta}$ are the continuous functions of the the vector argument; $\vec{X}^{*}$ is the optimum solution or optimum point (the vector of optimum values of the structural parameters); $f^{*}$ is the optimum value of the optimum criterion (objective function); $N_{E C}$ is the number of constraintsequalities $\psi_{\kappa}(\vec{X})$, whose define hyperplanes of the feasible solutions; $N_{I C}$ is the number of constraints-inequalities $\varphi_{\eta}(\vec{X})$, whose define a feasible region in the design space $\mathfrak{I}$.

The vector of the design variables comprises of unknown geometrical parameters of the structure $\vec{X}_{G}=\left\{X_{G, \chi}\right\}^{T}, \quad \chi=\overline{1, N_{X, G}}$, unknown crosssectional dimensions of the structural members $\vec{X}_{C S}=\left\{X_{C S, \alpha}\right\}^{T}, \alpha=\overline{1, N_{X, C S}}$, 
as well as unknown initial pre-stressing forces $\vec{X}_{P S}=\left\{X_{P S, \beta}\right\}^{T}, \beta=\overline{1, N_{X, P S}}$, introduced into the specified redundant members of the structure (see Figure 1.1):

$$
\vec{X}=\left\{\vec{X}_{G}, \vec{X}_{C S}, \vec{X}_{P S}\right\}^{T}=\left\{\left\{X_{G, \chi}\right\},\left\{X_{C S, \alpha}\right\},\left\{X_{P S, \beta}\right\}\right\}^{T},
$$

where $N_{X, G}$ is the total number of unknown node coordinates of the steel structure; $N_{X, C S}$ is the total number of unknown cross-sectional dimensions of the structural members, $N_{X, P S}$ is the total number of unknown initial prestressing forces introduced into the specified redundant members of the bar system, $N_{X, G}+N_{X, C S}+N_{X, P S}=N_{X}$.

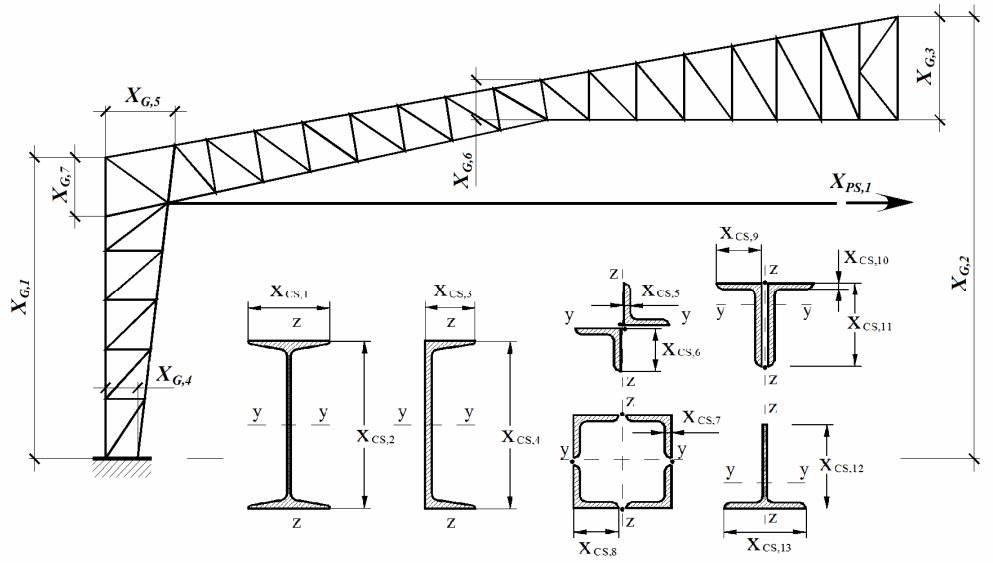

Fig. 1.1. The unknown (variable) parameters of the structure considered as design variables

In cases when vector of the design variables $\vec{X}$ consists of unknown crosssectional dimensions only:

$$
\vec{X}=\vec{X}_{C S}=\left\{X_{C S, \alpha}\right\}^{T} ;
$$

then optimum material distribution problem (1.1) - (1.3), (1.5) for the steel structure is under consideration. The vector of the design variables $\vec{X}$ can also consists of unknown initial pre-stressing forces $\vec{X}_{P S}=\left\{X_{P S, \beta}\right\}^{T}, \beta=\overline{1, N_{X, P S}}$, introduced into the specified redundant members of the structure:

$$
\vec{X}=\left\{\vec{X}_{C S}, \vec{X}_{P S}\right\}^{T}=\left\{\left\{X_{C S, \alpha}\right\},\left\{X_{P S, \beta}\right\}\right\}^{T},
$$

where $N_{X, C S}+N_{X, P S}=N_{X}$. In cases when vector of the design variables $\vec{X}$ consists of unknown cross-sectional dimensions and unknown initial prestressing forces, then optimum material and internal forces distribution problem (1.1) - (1.3), (1.6) for the steel structure is under consideration.

The specific technical-and-economic index (material weight, material cost, 
construction cost etc.) or another determined indicator can be considered as the objective function (1.1) taking into account the ability to formulate its analytical expression as a function of design variables $\vec{X}$.

Load-carrying capacities constraints (strength and stability inequalities) for all design sections of the structural members subjected to all design load combinations at the ultimate limit state as well as displacements constraints (stiffness inequalities) for the specified nodes of the bar system subjected to all design load combinations at the serviceability limit state should be included into the system of constraints (1.2) - (1.3). Additional requirements whose describe structural, technological and serviceability particularities of the considered structure can be included into the system (1.2) - (1.3) as well.

The design internal forces in the structural members used in the strength and stability inequalities of the system (1.2)-(1.3) are considered as state variables depending on design variables $\vec{X}$ and can be calculated from the following linear equations system of the finite element method [7]:

$$
\mathbf{K}\left(\vec{X}_{G}, \vec{X}_{C S}\right) \times \vec{z}_{U L S, k}=\vec{p}_{U L S, k}\left(\vec{X}_{G}, \vec{X}_{P S}\right), k=\overline{1, N_{L C}^{U L S}},
$$

where $\mathbf{K}\left(\vec{X}_{G}, \vec{X}_{C S}\right)$ is the stiffness matrix of the finite element model of the bar system, which should be formed depending on the unknown (variable) cross-sectional dimensions of the structural members $\vec{X}_{C S}$, as well as unknown (variable) node coordinates of the structure $\vec{X}_{G} ; \vec{p}_{U L S, k}\left(\vec{X}_{G}, \vec{X}_{P S}\right)$ is the column-vector of the node's loads for $k^{\text {th }}$ design load combination of the ultimate limit state, which should be formed depending on unknown (variable) initial pre-stressing forces $\vec{X}_{P S}$, as well as unknown (variable) node coordinates of the structure $\vec{X}_{G} ; \vec{z}_{U L S, k}$ is the result column-vector of the node displacements for $k^{\text {th }}$ design load combination of the ultimate limit state, $\vec{z}_{U L S, k}=\mathbf{Z}_{\mathbf{F E M}, k}^{U L S}\left(\vec{X}_{G}, \vec{X}_{C S}, \vec{X}_{P S}\right)=\mathbf{Z}_{\mathbf{F E M}, k}^{U L S}(\vec{X}) ; N_{L C}^{U L S}$ is the number of the design ultimate load combinations. For each $i^{\text {th }}$ design section of $j^{\text {th }}$ structural member subjected to $k^{\text {th }}$ ultimate design load combination the design internal forces (axial force, bending moments and shear forces) can be calculated depending on node displacement column-vector $\vec{z}_{U L S, k}$.

The node displacement of the bar system used in stiffness inequalities of the system (1.2) - (1.3) are also considered as state variables depending on design variables $\vec{X}$ and can be calculated from the following linear equations system of the finite element method [7]:

$$
\mathbf{K}\left(\vec{X}_{G}, \vec{X}_{C S}\right) \times \vec{z}_{S L S, k}=\vec{p}_{S L S, k}\left(\vec{X}_{G}, \vec{X}_{P S}\right), k=\overline{1, N_{L C}^{S L S}},
$$

where $\vec{p}_{S L S, k}\left(\vec{X}_{P S}\right)$ is the column-vector of the node's loads for $k^{\text {th }}$ design load combination of the serviceability limit state, which should be formed depending on unknown (variable) initial pre-stressing forces $\vec{X}_{P S}$, as well as 
unknown (variable) node coordinates of the structure $\vec{X}_{G} ; \vec{z}_{U L S, k}$ is the result column-vector of the node displacements for $k^{\text {th }}$ design load combination of the serviceability limit state, $\vec{z}_{S L S, k}=\mathbf{Z}_{\mathrm{FEM}, k}^{S L S}\left(\vec{X}_{G}, \vec{X}_{C S}, \vec{X}_{P S}\right)=\mathbf{Z}_{\mathbf{F E M}, k}^{S L S}(\vec{X}) ; N_{L C}^{S L S}$ is the number of the design serviceability load combinations. For each $\mathrm{m}^{\text {th }}$ node of the finite element model subjected to $k^{\text {th }}$ serviceability design load combination the design vertical and horizontal displacements can be calculated depending on node displacement column-vector $\vec{z}_{S L S, k}$.

The system of constraints (1.2) - (1.3) should cover strength and stability constraints formulated for all design sections of all structural members of the considered steel structure subjected to all design load combinations at the ultimate limit state. The following strength constraints should be included in the system of constraints (1.2)-(1.3), formulated for all design sections, $\forall i=\overline{1, N}_{D S}$, of all structural members, $\forall j=\overline{1, N_{B}}$, subjected to all ultimate load case combination, $\forall k=\overline{1, N_{L C}^{U L S}}$, namely:

- normal stresses verifications:

$$
\frac{\sigma_{\text {max }, i j k}(\vec{X})}{R_{y} \gamma_{c}}-1 \leq 0 ;
$$

- shear stresses verifications:

$$
\frac{\tau_{\text {max }, j i k}(\vec{X})}{0.58 R_{y} \gamma_{c}}-1 \leq 0 ;
$$

- as well as equivalent stresses verifications:

$$
\frac{\sigma_{e q v, j i k}(\vec{X})}{1.15 R_{y} \gamma_{c}}-1=\frac{\sqrt{\sigma_{x, i j k}^{2}(\vec{X})+3 \tau_{x, j i k}^{2}(\vec{X})}}{1.15 R_{y} \gamma_{c}}-1 \leq 0,
$$

where $\sigma_{\text {max }, i j k}(\vec{X})$ are $\tau_{\text {max }, i j k}(\vec{X})$ are the maximum value of the normal and shear stresses respectively caused by internal forces (axial force, bending moments and shear forces) acting in $i^{\text {th }}$ design section of $j^{\text {th }}$ structural member subjected to $k^{\text {th }}$ ultimate load case combination calculated from the linear equations system of the finite element method (1.7); $\gamma_{c}$ is the safety factor [4]; $R_{y}$ is the design strength for steel member subjected to tension, bending and compression; $R_{y} \gamma_{c}, 0.58 R_{y} \gamma_{c}$ and $1.15 R_{y} \gamma_{c}$ are allowable values for normal, shear and equivalent stresses respectively [4]; $N_{D S}$ is the number of design sections in structural members; $N_{B}$ is the number of structural members; $\sigma_{x, j i k}(\vec{X}), \tau_{x, i j k}(\vec{X})$ and $\sigma_{e q v, i j k}(\vec{X})$ are normal, shear and equivalent stresses respectively at the specified cross-section point caused by internal forces acting in $i^{\text {th }}$ design section of $j^{\text {th }}$ structural member subjected to $k^{\text {th }}$ ultimate load case combination calculated from the linear equations system of 
the finite element method (1.7). The maximum value of the normal $\sigma_{\text {max }, i j k}(\vec{X})$ and shear stresses $\tau_{\text {max }, i j k}(\vec{X})$, as well as normal $\sigma_{x, i j k}(\vec{X})$, shear $\tau_{x, i j k}(\vec{X})$ and equivalent $\sigma_{e q v, i j k}(\vec{X})$ stresses at the specified cross-section point should be calculated depending on the variable geometrical parameters of the structure $\vec{X}_{G}$, variable initial pre-stressing forces $\vec{X}_{P S}$ and variable cross-sectional dimensions of the structural members $\vec{X}_{C S}$.

The following stability constraints should be included in the system of constraints (1.2)-(1.3), formulated for all design sections, $\forall i=\overline{1, N}_{D S}$, subjected to all ultimate load case combination, $\forall k=\overline{1, N_{L C}^{U L S}}$, namely:

- flexural buckling verifications for all column structural members, $\forall j=\overline{1, N_{C M}}$ :

$$
\begin{gathered}
\frac{\sigma_{\text {max }, i j k}(\vec{X})}{\varphi_{y, j}\left(\vec{X}_{G}, \vec{X}_{C S}\right) R_{y} \gamma_{c}}-1 \leq 0, \\
\frac{\sigma_{\text {max }, j i k}(\vec{X})}{\varphi_{z, j}\left(\vec{X}_{G}, \vec{X}_{C S}\right) R_{y} \gamma_{c}}-1 \leq 0 ;
\end{gathered}
$$

- torsional-flexural buckling verifications for all column structural members, $\forall j=\overline{1, N_{C M}}$ :

$$
\frac{\sigma_{\max , i j k}(\vec{X})}{\varphi_{c, j}\left(\vec{X}_{G}, \vec{X}_{C S}\right) R_{y} \gamma_{c}}-1 \leq 0 ;
$$

- lateral-torsional buckling verifications for all beam structural members, $\forall j=\overline{1, N_{B M}}$ :

$$
\frac{\sigma_{\max , i j k}(\vec{X})}{\varphi_{b, j}\left(\vec{X}_{G}, \vec{X}_{C S}\right) R_{y} \gamma_{c}}-1 \leq 0,
$$

where $\varphi_{y, j}\left(\vec{X}_{G}, \vec{X}_{C S}\right)$ and $\varphi_{z, j}\left(\vec{X}_{G}, \vec{X}_{C S}\right)$ are column's stability factors corresponded to flexural buckling relative to main axes of inertia and calculated depending on the design lengths $l_{e f, y, j}, l_{e f, z, j}$, cross-section type and crosssection geometrical properties for the $j^{\text {th }}$ structural member [4]; $\varphi_{c, j}\left(\vec{X}_{G}, \vec{X}_{C S}\right)$ is the column's stability factor corresponded to torsional-flexural buckling and calculated depending on the design lengths $l_{e f, y, j}, l_{e f, z, j}, l_{e f, T, j}$, cross-section type and cross-section geometrical properties for the $j^{\text {th }}$ structural member[4]; $N_{C M}$ is the number of column structural members; $\varphi_{b, j}\left(\vec{X}_{G}, \vec{X}_{C S}\right)$ is the beam's stability factor corresponded to lateral-torsional buckling and calculated depending on the design length $l_{e f, b, j}$, cross-section type and cross-section 
geometrical properties for the $j^{\text {th }}$ structural member [4]; $N_{B M}$ is the number of beam structural members. The flexural buckling factors $\varphi_{y, j}\left(\vec{X}_{G}, \vec{X}_{C S}\right)$ and $\varphi_{z, j}\left(\vec{X}_{G}, \vec{X}_{C S}\right)$, as well as torsional-flexural buckling factor $\varphi_{c, j}\left(\vec{X}_{G}, \vec{X}_{C S}\right)$ and the lateral-torsional buckling factor $\varphi_{b, j}\left(\vec{X}_{G}, \vec{X}_{C S}\right)$ should be calculated depending on the variable geometrical parameters of the structure $\vec{X}_{G}$ and variable cross-sectional dimensions of the structural members $\vec{X}_{C S}$.

The following buckling verifications for beam-column structural members should also be included in the system of constraints (1.2) - (1.3), formulated for all design sections, $\forall i=\overline{1, N}_{D S}$, of all beam-column structural members, $\forall j=\overline{1, N_{B C M}}$, subjected to all ultimate load case combination, $\forall k=\overline{1, N_{L C}^{U L S}}$, namely:

$$
\begin{gathered}
\frac{\sigma_{\text {max }, i j k}(\vec{X})}{\varphi_{e, i j k}(\vec{X}) R_{y} \gamma_{c}}-1 \leq 0, \\
\frac{\sigma_{\text {max }, i j k}(\vec{X})}{\varphi_{y, j}\left(\vec{X}_{G}, \vec{X}_{C S}\right) c_{i j k}(\vec{X}) R_{y} \gamma_{c}}-1 \leq 0,
\end{gathered}
$$

where $\varphi_{e, i j k}(\vec{X})$ and $c_{i j k}(\vec{X})$ are beam-column's stability factors corresponded to in-plane and out-of-plane buckling and calculated depending on the internal forces (ration of the bending moment to the axial force), as well as depending on the design lengths $l_{e f, y, j}, l_{e f, z, j}$, cross-section type and cross-section geometrical properties for the $j^{\text {th }}$ structural member [4]; $N_{B C M}$ is the total number of beam-column structural members, $N_{B C M}+N_{C M}+N_{B M}=N_{B}$. The beam-column's stability factors $\varphi_{e, i j k}(\vec{X})$ and $c_{i j k}(\vec{X})$ should be calculated depending on variable geometrical parameters of the structure $\vec{X}_{G}$, variable cross-sectional dimensions of the structural members $\vec{X}_{C S}$ and variable initial pre-stressing forces $\vec{X}_{P S}$.

The following local buckling constraints should also be included into the system of constraints:

$$
\begin{aligned}
& \frac{\bar{\lambda}_{w, j}\left(\vec{X}_{C S}\right)}{\bar{\lambda}_{u w, j}(\vec{X})}-1 \leq 0, \\
& \frac{\bar{\lambda}_{f, j}\left(\vec{X}_{C S}\right)}{\bar{\lambda}_{u f, j}(\vec{X})}-1 \leq 0,
\end{aligned}
$$

where $\bar{\lambda}_{w, j}\left(\vec{X}_{C S}\right)$ and $\bar{\lambda}_{f, j}\left(\vec{X}_{C S}\right)$ are the non-dimensional slenderness of the web and flange respectively of the cross-section for $j^{\text {th }}$ structural member; 
$\bar{\lambda}_{u w, j}(\vec{X})$ and $\bar{\lambda}_{u f, j}(\vec{X})$ are the maximum values for corresponded nondimensional slenderness for column, beam and beam-column structural members calculated depending on the internal forces (ration of the bending moment to the axial force), as well as depending on the design lengths $l_{e f, y, j}$, $l_{e f, z, j}$, cross-section type and cross-section geometrical properties for the $j^{\text {th }}$ structural member [4]. The non-dimensional slenderness $\bar{\lambda}_{w, j}\left(\vec{X}_{C S}\right)$ and $\bar{\lambda}_{f, j}\left(\vec{X}_{C S}\right)$ should be calculated depending on the variable cross-sectional dimensions of the structural members $\vec{X}_{C S}$ only. At the same time, the maximum values for corresponded non-dimensional slenderness $\bar{\lambda}_{u w, j}(\vec{X})$ and $\bar{\lambda}_{u f, j}(\vec{X})$ should be calculated depending on the variable geometrical parameters of the structure $\vec{X}_{G}$ and variable cross-sectional dimensions of the structural members $\vec{X}_{C S}$ and variable initial pre-stressing forces $\vec{X}_{P S}$.

The system of constraints (1.2) - (1.3) should also cover the displacements constraints (stiffness inequalities) for the specified nodes of the considered steel structure subjected to all design load combinations at the serviceability limit state. The following horizontal and vertical displacements constraints should be included into the system of constraints (1.2) - (1.3), formulated for all nodes, $\forall m=\overline{1, N_{N}}$, of the steel structure subjected to all serviceability load case combination, $\forall k=\overline{1, N_{L C}^{S L S}}$, namely:

$$
\begin{aligned}
& \frac{\delta_{x, m k}(\vec{X})}{\delta_{u x, m}}-1 \leq 0, \\
& \frac{\delta_{z, m k}(\vec{X})}{\delta_{u z, m}}-1 \leq 0,
\end{aligned}
$$

where $\delta_{x, m k}(\vec{X})$ and $\delta_{z, l k}(\vec{X})$ are the horizontal and vertical displacements respectively for $l^{\text {th }}$ node of the steel structure subjected to $k^{\text {th }}$ serviceability load case combination calculated from the linear equations system of the finite element method (1.8); $\delta_{u x, l}$ and $\delta_{u z, l}$ are the allowable horizontal and vertical displacements for $l^{\text {th }}$ structural node; $N_{N}$ is the number of nodes in the considered steel structure.

Additional requirements, whose describe structural, technological and serviceability particularities of the considered structure, as well as constraints on the building functional volume can be also included into the system (1.2) (1.3). In particular these requirements can be presented in the form of constraints on lower and upper values of the design variables, $\forall \imath=\overline{1, N_{X}}$ : 


$$
\begin{aligned}
& 1-\frac{X_{\iota}}{X_{\iota}^{L}} \leq 0, \\
& \frac{X_{\iota}}{X_{l}^{U}}-1 \leq 0,
\end{aligned}
$$

where $X_{l}^{L}$ and $X_{l}^{U}$ are the lower and upper bounds for the design variable $X_{l}$.

2. An improved gradient projection method for solving the formulated parametric optimisation problem. The parametric optimization problem stated as non-linear programming task by (1.1) - (1.3) can be solved using a gradient projection method. The method of objective function gradient projection onto the active constraints surface with simultaneous correction of the constraints violations ensures effective searching for solution of the nonlinear programming tasks occurred when optimum designing of the building structures $[9,11]$.

The gradient projection method operates with the first derivatives or gradients only of both the objective function (1.1) and constraints (1.2) - (1.3). The method is based on the iterative construction of such sequence (2.1) of the approximations of the design variables $\vec{X}=\left\{X_{\imath}\right\}^{T}, \imath=\overline{1, N_{X}}$, that provides the convergence to the optimum solution (optimum values of the structural parameters):

$$
\vec{X}_{t+1}=\vec{X}_{t}+\Delta \vec{X}_{t},
$$

where $\vec{X}_{t}=\left\{X_{l}\right\}^{T}, \imath=\overline{1, N_{X}}$ is the current approximation to the optimum solution $\vec{X}^{*}$ that satisfies both constraints-equalities (1.2) and constraintsinequalities (1.3) with the extreme value of the objective function (1.1); $\Delta \vec{X}_{t}=\left\{\Delta X_{t}\right\}^{T}, \imath=\overline{1, N_{X}}$, is the increment vector for the current values of the design variables $\vec{X}_{t} ; t$ is the iteration's index. The start point of the iterative searching process $\vec{X}_{t=0}$ can be assigned as engineering estimation of the admissible design of the structure.

The active constraints only of constraints system (1.2) - (1.3) should be considered at each iteration. A set of active constraints numbers $\mathbf{A}$ calculated for the current approximation $\vec{X}_{t}$ to the optimum solution (current design of the structure) is determined as:

$$
\mathbf{A}=\boldsymbol{\kappa} \cup \boldsymbol{\eta}, \boldsymbol{\kappa}=\left\{\kappa|| \psi_{\kappa}\left(\vec{X}_{t}\right) \mid \geq-\varepsilon\right\}, \boldsymbol{\eta}=\left\{N_{E C}+\eta \mid \phi_{\eta}\left(\vec{X}_{t}\right) \geq-\varepsilon\right\},
$$

where $\varepsilon$ is a small positive number introduced here in order to diminish the oscillations on movement alongside of the active constraints surface.

The increment vector $\Delta \vec{X}_{t}$ for the current values of the design variables $\vec{X}_{t}$ can be determined by the following equation: 


$$
\Delta \vec{X}_{t}=\Delta \vec{X}_{\perp}^{t}+\Delta \vec{X}_{\|}^{t},
$$

where $\Delta \vec{X}_{\perp}^{t}$ is the vector calculated subject to the condition of elimination the constraint's violations; $\Delta \vec{X}_{\|}^{t}$ is the vector determined taking into consideration the improvement of the objective function value. Vectors $\Delta \vec{X}_{\|}^{t}$ and $\Delta \vec{X}_{\perp}^{t}$ are directed parallel and perpendicularly accordingly to the subspace with the vectors basis of the linear-independent constraint's gradients, such that:

$$
\left(\Delta \vec{X}_{\perp}^{t}\right)^{T} \Delta \vec{X}_{\|}^{t}=0 .
$$

The values of the constraint's violations for the current approximation $\vec{X}_{t}$ of the design variables are accumulated into the following vector:

$$
\mathbf{V}=\left(\psi_{\kappa}(\vec{X}) \forall \kappa \in \mathbf{\kappa} ; \phi_{\eta}(\vec{X}) \forall \eta \in \boldsymbol{\eta}\right) .
$$

Let us introduce a set $\mathbf{L}, \mathbf{L} \subseteq \mathbf{A}$, of the constraint's numbers, such that the gradients of the constraints at the current approximation $\vec{X}_{t}$ to the optimum solution are linear-independent.

Component $\Delta \vec{X}_{\perp}^{t}$ is calculated from the equation presented below:

$$
\Delta \vec{X}_{\perp}^{t}=[\nabla \varphi] \vec{\mu}_{\perp},
$$

where $[\nabla \varphi]$ is the matrix that consists of components $\frac{\partial \psi_{\kappa}}{\partial X_{t}}$ and $\frac{\partial \phi_{\eta}}{\partial X_{t}}$, here $\imath=\overline{1, N_{X}}, \kappa \in \mathbf{L}, \eta \in \mathbf{L} ; \vec{\mu}_{\perp}$ is the column-vector that defines the design variables increment subject to the condition of elimination the constraint's violations. Vector $\vec{\mu}_{\perp}$ can be calculated as presented below.

In order to correct constraint's violations $\mathbf{V}$, vector $\Delta \vec{X}_{\perp}^{t}$ to a first approximation should also satisfy Taylor's theorem for the continuously differentiable multivariable function in the vicinity of point $\vec{X}_{t}$ for each constraint from set $\mathbf{L}$, namely:

$$
-\mathbf{V}=[\nabla \varphi]^{T} \Delta \vec{X}_{\perp}^{t} .
$$

With substitution of (2.5) into (2.6) we obtain the system of equations to determine column-vector $\vec{\mu}_{\perp}$ :

$$
[\nabla \varphi]^{T}[\nabla \varphi] \vec{\mu}_{\perp}=-\mathbf{V} .
$$

Component $\Delta \vec{X}_{\|}^{t}$ is determined using the following equation:

$$
\Delta \vec{X}_{\|}^{t}=\xi \times \vec{p}_{\nabla f}=\xi\left(\nabla \vec{f}-[\nabla \varphi] \vec{\mu}_{\|}\right),
$$

where $\nabla \vec{f}$ is the vector of the objective function gradient in the current point 
(current approximation of the design variables) $\vec{X}_{t} ; \vec{p}_{\nabla f}$ is the projection of the objective function gradient vector onto the active constraints surface in the current point $\vec{X}_{t} ; \vec{\mu}_{\|}$is the column-vector that defines the design variable's increment subject to the improvement of the objective function value. Columnvector $\vec{\mu}_{\|}$can be calculated approximately using the least-square method by the following equation:

$$
[\nabla \varphi] \vec{\mu}_{\|} \approx \nabla \vec{f},
$$

or from the equation presented below:

$$
[\nabla \varphi]^{T}[\nabla \varphi] \vec{\mu}_{\|}=[\nabla \varphi]^{T} \nabla \vec{f}
$$

where $\xi$ is the step parameter, which can be calculated subject to the desired increment $\Delta f$ of the purpose function on movement along the direction of the purpose function anti-gradient. The increment $\Delta f$ can be assign as $5 \ldots 25 \%$ from the current value of the objective function $f\left(\vec{X}_{t}\right)$ :

$$
\Delta f=\xi(\nabla \vec{f})^{T} \nabla \vec{f}, \xi=\frac{\Delta f}{(\nabla \vec{f})^{T} \nabla \vec{f}},
$$

where in case of minimization (1.1) $\Delta f$ and $\xi$ accordingly have negative values. The parameter $\xi$ can be also calculated using the dependency presented below:

$$
\xi=\frac{\Delta f}{\left(\vec{p}_{\nabla f}\right)^{T} \nabla \vec{f}},
$$

that follows from the condition of attainment the desired increment of the objective function $\Delta f$ on the movement along the direction of the objective function anti-gradient projection onto the active constraints surface. Step parameter $\xi$ can be also selected as a result of numerical experiments performed for each type of the structure individually $[6,15]$.

Using (2.5) and (2.8), (2.3) can be rewritten as presented below:

$$
\Delta \vec{X}_{t}=[\nabla \varphi] \vec{\mu}_{\perp}+\xi\left(\nabla \vec{f}-[\nabla \varphi] \vec{\mu}_{\|}\right)
$$

or

$$
\Delta \vec{X}_{t}=\xi \nabla \vec{f}+[\nabla \varphi]\left(\vec{\mu}_{\perp}-\xi \vec{\mu}_{\|}\right),
$$

where column-vectors $\vec{\mu}_{\perp}$ and $\vec{\mu}_{\|}$are calculated using (2.7) and (2.9) or (2.10), respectively.

The linear-independent constraints of the system (1.2) - (1.3) should be detected when constructing the matrix of the active constraints gradients $[\nabla \varphi]$ used by (2.7) and (2.9) or (2.10). Selection of the linear-independent constraints can be performed based on the equivalent transformations of the 
resolving equations of the gradient projection method using the non-degenerate transformation matrix $\mathbf{H}$, such that the sub-diagonal elements of the matrix $\mathbf{H}[\nabla \varphi]$ equal to zero. An orthogonal matrix of the elementary mapping (Householder's transformation) [17] has been used to select linear-independent constraints of the system (1.2) - (1.3) as well as to form triangular structure of the nonzero elements of matrix $\mathbf{H}[\nabla \varphi][12]$.

Using Householder's transformations described above triangular structure of the nonzero elements of matrix $\mathbf{H}[\nabla \varphi]$ is formed step-by-step. Besides, (2.7) and (2.9) can be rewritten as follow:

$$
\begin{gathered}
\left([\nabla \varphi]^{T} \mathbf{H}^{T}\right)(\mathbf{H}[\nabla \varphi]) \vec{\mu}_{\perp}=-\mathbf{V}, \\
\mathbf{H}[\nabla \varphi] \vec{\mu}_{\square} \approx \mathbf{H} \nabla \vec{f} .
\end{gathered}
$$

Equivalent Householder transformations of the resolving equations (2.15), (2.16) have been proposed by the paper [12]. They increase numerical efficiency of the algorithm developed based on the considered method.

In order to calculate column-vectors $\vec{\mu}_{\perp}$ and $\vec{\mu}_{\|}$, it is required only to perform forward and backward substitutions in (2.15) and (2.16).

To accelerate the convergence of the minimization algorithm presented above, $h^{\text {th }}$ columns should be excluded from matrix $\mathbf{H}[\nabla \varphi]$. These columns correspond to those constraints from (1.3), for whose the following inequality satisfies:

$$
\mu_{\perp h}-\xi \times \mu_{\llcorner h}>0 .
$$

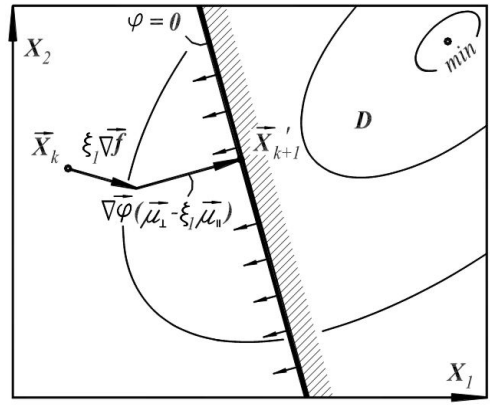

(a)

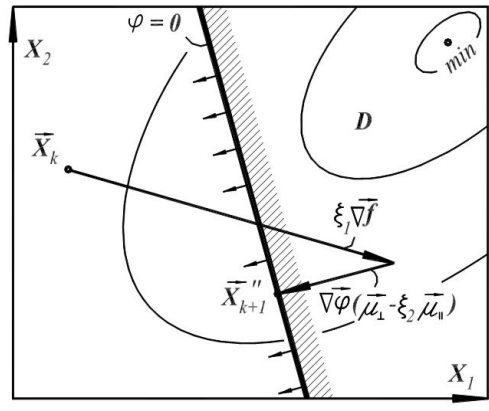

(b)

Fig. 2.1. The selection of the constraints-inequalities:

(a) $-\mu_{\perp h}-\xi_{1} \times \mu_{\llcorner h}<0$; (b) $-\mu_{\perp h}-\xi_{2} \times \mu_{\llcorner h}>0$.

Actually, when $\mu_{\perp h}-\xi \times \mu_{\llcorner h}>0$, then the return onto the active constraints surface from the feasible region $\mathfrak{I}$ is performed with simultaneous degradation of the objective function value (see Fig. 2.1b). At the same time, in case of $\mu_{\perp h}-\xi \times \mu_{\perp h}<0$, both the improvement of the objective function 
value and the return from the inadmissible region onto the active constraints surface are performed (see Fig. 2.1a).

When excluding $h^{\text {th }}$ columns from matrix $\mathbf{H}[\nabla \varphi]$ corresponded to those constraints for whose (2.17) is satisfied, the matrix $(\mathbf{H}[\nabla \varphi])_{\text {red }}$ with a broken (non-triangular) structure of the non-zero elements is obtained. The set $\mathbf{L}$ of the linear-independent active constraints numbers transforms into the set $\mathbf{L}_{\text {red }}$ respectively. At the same time, the vector of the constraint's violations $\mathbf{V}$ reduced into the vector $\mathbf{V}_{\text {red }}$ accordingly. In order to restore the triangular structure of the matrix $(\mathbf{H}[\nabla \varphi])_{\text {red }}$ with zero sub-diagonal elements, Givens transformations (Givens rotations) [17] can be used.

Considering Givens transformations, (2.15) and (2.16) for column-vectors $\left(\vec{\mu}_{\perp}\right)_{\text {red }}$ and $\left(\vec{\mu}_{\square}\right)_{\text {red }}$ can be rewritten as:

$$
\begin{gathered}
\left([\nabla \varphi]^{T} \mathbf{H}^{T}\right)_{\text {red }} \mathbf{G}^{T} \mathbf{G}(\mathbf{H}[\nabla \varphi])_{\text {red }}\left(\vec{\mu}_{\perp}\right)_{\text {red }}=-\mathbf{V}_{\text {red }}, \\
\mathbf{G}(\mathbf{H}[\nabla \varphi])_{\text {red }}\left(\vec{\mu}_{\sqcup}\right)_{\text {red }} \approx \mathbf{G H} \nabla \vec{f} .
\end{gathered}
$$

Equivalent transformations of the resolving equations (2.18), (2.19) using Givens rotations (transformations with matrix $\mathbf{G}$ ) ensure acceleration of the iterative searching process (2.1) in those cases when (2.17) takes into account due to decreasing the amount of calculations [12].

The main resolving equation of the gradient method (2.13) and (2.14) can be rewritten as presented below:

$$
\Delta \vec{X}_{t}=(\mathbf{H}[\nabla \varphi])_{\text {red }}\left(\vec{\mu}_{\perp}\right)_{\text {red }}+\xi\left(\nabla \vec{f}-(\mathbf{H}[\nabla \varphi])_{\text {red }}\left(\vec{\mu}_{\|}\right)_{\text {red }}\right)
$$

or

$$
\Delta \vec{X}_{t}=\xi \nabla \vec{f}+(\mathbf{H}[\nabla \varphi])_{\text {red }}\left(\left(\vec{\mu}_{\perp}\right)_{\text {red }}-\xi\left(\vec{\mu}_{\|}\right)_{\text {red }}\right) .
$$

It should be noted that the lengths of the gradient vectors for the objective function (1.1), as well as for constraints (1.2)-(1.3), remain as they were in scope of the proposed equivalent transformations ensuring the dependability of the optimization algorithm [12].

The determination the convergence criterion is the final question when using the iterative searching for the optimum point (2.1) described above. Considering the geometrical content of the gradient steepest descent method, we can assume that at the permissible point $\vec{X}_{t}$ the component of the increment vector $\Delta \vec{X}_{\|}^{t}$ for the design variables should be vanish, $\Delta \vec{X}_{\|}^{t} \rightarrow 0$, in case of approximation to the optimum solution of the non-linear programming task presented by (1.1) - (1.5). So, the following convergence criterion of the iterative procedure (2.1) can be assigned:

$$
\left\|\Delta \vec{X}_{\|}^{k}\right\|=\sqrt{\sum_{\imath=1}^{N_{X}}\left(\Delta X_{\|, \imath}^{k}\right)^{2}}<\varepsilon_{1}
$$


where $\varepsilon_{1}$ is a small positive number. In the paper [12] the convergence criteria for the iterative procedure (2.1) has been presented in detail.

3. A parametric optimization algorithm based on the gradient projection method. Let us presented the following numerical algorithm to solve the parametric optimization problem for steel structures formulated above.

Step 1. Describing an initial design (a set of design variables) and initial data for structural optimization.

The design variable vector $\vec{X}_{k}=\left(\vec{X}_{G}, \vec{X}_{C S}, \vec{X}_{P S}\right)_{k}^{T}$ should be specified, where $k$ is the iteration index, $k=0$. The structural topology, cross-section types and node type connections of the bars, the support conditions of the bar system, as well as loading and pre-stressing patterns, load case combinations and load design values are prescribed and constants.

Initial data for optimization of the considered steel structure are design strength for steel member $R_{y}$, safety factor $\gamma_{c}$, factors to define flexural design lengths $l_{e f, y, j}, l_{e f, z, j}$ and flexural-torsional design length $l_{e f, T, j}$ for all column structural members; factor to define lateral-torsional design length $l_{e f, b, j}$ for all beam structural members; allowable values for horizontal and vertical displacements $\delta_{u x, l}$ and $\delta_{u z, l}$ of the specified nodes of the considered steel structure; lower $\vec{X}^{L}$ and upper $\vec{X}^{U}$ bounds for the design variables; as well as specified objective function $f\left(\vec{X}_{k}\right)$.

Step 2. Calculation of the geometrical and design lengths for all structural members.

The geometrical lengths $l_{j}$ of all structural members are calculated based on the node coordinates of the considered steel structure. The latter depend on the unknown (variable) geometrical parameters of the structure $\vec{X}_{G}$. The design lengths $l_{e f, y, j}, l_{e f, z, j}$ and $l_{e f, T, j}$ of all column structural members are calculated using calculated geometrical lengths $l_{j}$ and initial data relating to the design length factors. Variation of the geometrical lengths $l_{j}$ and corresponded design lengths $l_{e f, y, j}, l_{e f, z, j}$ and $l_{e f, T, j}$ on the further iterations should be performed based on the current values of the variable (unknown) parameters $\vec{X}_{G}$ of the geometrical scheme.

Step 3. Calculation of the cross-section dimensions and geometrical properties for all design cross-sections.

Geometrical properties of the design cross-sections (areas, moments of inertia, elastic section moments, radiuses of inertia, etc.), as well as nondimensional slenderness for cross-section elements (webs and flanges) $\bar{\lambda}_{w, j}\left(\vec{X}_{C S}\right)$ and $\bar{\lambda}_{f, j}\left(\vec{X}_{C S}\right)$ should be calculated depending on the current 
values of the unknown (variable) cross-section dimensions $\vec{X}_{C S}$.

Step 4. Linear structural analysis of the considered steel structure.

For each $m^{\text {th }}$ node of the finite element model subjected to $k^{\text {th }}$ serviceability load case combination the displacements and rotations, as well as the design horizontal $\delta_{x, m k}(\vec{X})$ and vertical $\delta_{z, l k}(\vec{X})$ displacements can be calculated using the linear equations system of the finite element method (1.8).

For each $i^{\text {th }}$ design section of $j^{\text {th }}$ structural member subjected to $k^{\text {th }}$ ultimate load case combination the design internal forces can be calculated using the linear equations system of the finite element method (1.7).

Step 5. Calculation of the state variables (stresses, buckling factors, allowable non-dimensional slenderness etc.).

The maximum value of the normal $\sigma_{\text {max, }, j k}(\vec{X})$ and shear stresses $\tau_{\text {max }, i j k}(\vec{X})$, as well as normal $\sigma_{x, i j k}(\vec{X})$, shear $\tau_{x, i j k}(\vec{X})$ and equivalent $\sigma_{\text {eqv }, i j k}(\vec{X})$ stresses at the specified cross-section point should be calculated depending on the internal forces (axial force, bending moments and shear forces) acting in $i^{\text {th }}$ design section of $j^{\text {th }}$ structural member subjected to $k^{\text {th }}$ ultimate load case combination as presented by the design code.

The flexural buckling factors $\varphi_{y, j}\left(\vec{X}_{G}, \vec{X}_{C S}\right), \varphi_{z, j}\left(\vec{X}_{G}, \vec{X}_{C S}\right)$, torsionalflexural buckling factor $\varphi_{c, j}\left(\vec{X}_{G}, \vec{X}_{C S}\right)$ for column structural members, as well as the lateral-torsional buckling factor $\varphi_{b, j}\left(\vec{X}_{G}, \vec{X}_{C S}\right)$ for beam structural members should be calculated depending on the corresponded design lengths, cross-section type and cross-section geometrical properties for the structural members according to the design code [4]. The stability factors $\varphi_{e, j i k}(\vec{X})$ and $c_{i j k}(\vec{X})$ for beam-column structural members should be calculated depending on the ration of the bending moment to the axial force, as well as depending on the corresponded design lengths, cross-section type and cross-section geometrical properties for the structural members according to the design code [4].

The maximum values for corresponded non-dimensional slenderness $\bar{\lambda}_{u w, j}(\vec{X})$ and $\bar{\lambda}_{u f, j}(\vec{X})$ for column, beam and beam-column structural members should be calculated depending on the internal forces (ration of the bending moment to the axial force), as well as depending on the design lengths $l_{e f, y, j}, l_{e f, z, j}$, cross-section type and cross-section geometrical properties for the $j^{\text {th }}$ structural member [4].

Step 6. Verifications of the constraints and construction the set of active constraints numbers A .

Verification of the constraints (1.9) - (1.17) should be performed for all ultimate load case combinations and all design cross-sections of all structural members. Verification of the constraints (1.20)-(1.21) should be also 
conducted for all serviceability load case combinations and all design structural nodes. Additional requirements $(1.22)-(1.23)$ in the form of constraints on lower and upper values of the design variables, as well as local buckling constraints (1.18) - (1.19) should also be verified. Set of active constraints numbers A calculated for the current approximation $\vec{X}_{k}$ should be constructed according to (2.2).

Step 7. Calculation of the current objective function value $f\left(\vec{X}_{k}\right)$, objective function gradient $\nabla f\left(\vec{X}_{k}\right)$ and determination of the desired decrement of the objective function value $\Delta f\left(\vec{X}_{k}\right)$.

The objective function gradient $\nabla f\left(\vec{X}_{k}\right)$ can be calculated by the numerical differentiation with respect to the design variables using the finite difference approximation. The desired decrement of the objective function value $\Delta f\left(\vec{X}_{k}\right)$ can be assigned as $5 . .25 \%$ from the current objective function value $f\left(\vec{X}_{k}\right)$.

Step 8. Construction of the constraint's violations vector $\mathbf{V}$ and the matrix of the active constraint's gradients $[\nabla \varphi]$. The vector of the values of the constraint's violations $\mathbf{V}$ and the matrix of the constraint's gradients $[\nabla \varphi]$ are constructed for active constraints only according to the set of active constraints numbers A .

Step 9. Construction the matrix of active linear-independent constraint's gradients with triangular structure. The set of linear-independent constraint's numbers $\mathbf{L}$ and the matrix of active linear-independent constraint's gradients $\mathbf{H}[\nabla \varphi]$ with triangular structure are constructed according to the algorithm presented by the paper [12].

Step 10. Step parameter $\xi$ calculation. Step parameter $\xi$ should be calculated according to (2.10) or (2.11) and can be modified on the further iterations depending on convergence of the iterative process (2.1).

Step 11. Calculation the column-vectors $\vec{\mu}_{\perp}$ and $\vec{\mu}_{\square}$ which define the design variables increment subject to the condition of elimination the constraint's violations and subject to the improvement of the objective function value. The vectors $\vec{\mu}_{\perp}$ and $\vec{\mu}_{\square}$ can be calculated using (2.19) and (2.20) respectively.

If some $h^{\text {th }}$ component of the column-vectors $\vec{\mu}_{\perp}$ and $\vec{\mu}_{\square}$ satisfies (2.12), the corresponded constraint gradient $\nabla \varphi_{h}$ should be excluded from the matrix $[\nabla \varphi]$, and corresponded violations $V_{h}$ should be excluded from the vector $\mathbf{V}$, as well as the return to step 9 has to be conducted. In contrary case transition to the step 11 should be performed.

Step 12. Calculation the increment vector for the current design variables 
and determination the improved approximation to the optimum solution. The increment vector $\Delta \vec{X}_{k}$ for the current design variables values $\vec{X}_{k}$ should be calculated according to (2.20) or (2.21). The improved approximation $\vec{X}_{k+1}$ to the optimum solution should be determined according to (2.1).

Step 13. Stop criteria verification of iterative searching for the optimum solution. If all constraints (1.9) - (1.23) are satisfied with appropriate accuracy, as well as inequality (2.22) or one of the stop criteria described by the paper [12] is also satisfied, then transition to the step 13 should be performed. In contrary case return to the step 1 should be conducted with $k \leftarrow k+1$.

Step 14. Discretization the optimum solution $\vec{X}_{k}$ obtained in the continuum space of the design variables.

Step 15. Optimum parameters of the structure is $\vec{X}_{k}$ with optimum value of the objective function $f\left(\vec{X}_{k}\right)$.

Figure 3.1 presents the flow chart for structural optimization according to the searching technique describing by the gradient projection method considered above.

4. Results and discussion. In order to estimate an efficiency of the new methods or algorithms, a comparison with alternative methods or algorithms presented by other authors using different optimization techniques should be performed. Criteria to implement such comparison are described, e.g. by Haug and Arora [6] and Crowder et al. [3]. Many of these criteria, such as robustness, amount of functions calculations, requirements to the computer memory, numbers of iterations etc. cannot be used due to lack of corresponded information in the technical literature. Therefore, an efficiency estimation of the proposed methodology for solving parametric optimization problems presented above will be based on the comparison of the optimization results obtained using the proposed numerical algorithm, as well as of the results presented by the literature and widely used for testing. The initial data and mathematical models of the parametric optimization problems considered below were assumed as the same as described in the literature.

4.1. Geometry and cross-sectional optimization of a 19-bar cantilever truss. Figure 4.1 shows a 19-bar cantilever truss designed for the vertical loads $P=10 \mathrm{kN}$. Table 4.1 presents initial data for truss optimum design. There were no lower and upper bounds for the cross section areas for all truss members. 


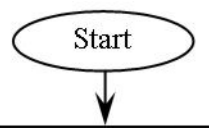

Step 1. Describing an initial design (a set of design variables) and initial data for structural optimization. $k$ is the iteration index, $k=0$.

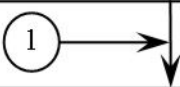

Step 2. Calculation of the geometrical and design lengths for all members.

Step 3. Calculation of the cross-section dimensions and geometrical properties for all design cross-sections.

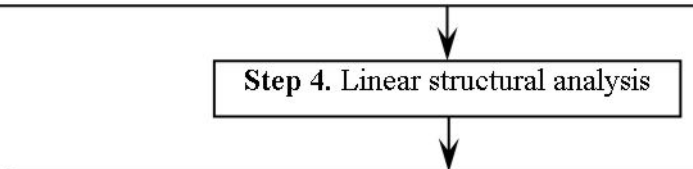

Step 5. Calculation of the state variables (internal forces, stresses, etc.)

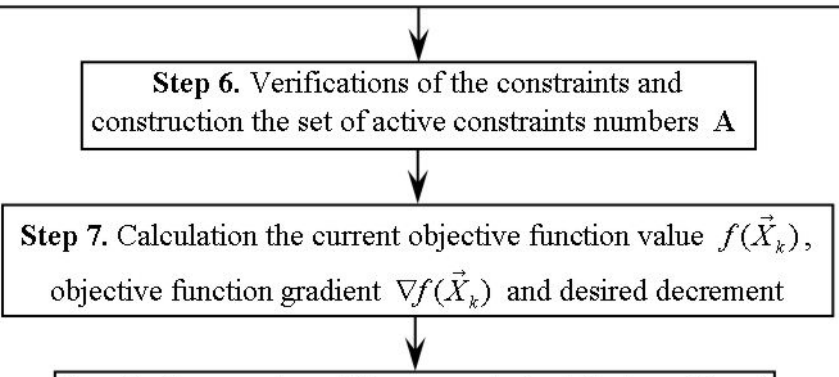

Step 8. Construction of the constraint's violations $\mathrm{V}$ and the matrix of the active constraint's gradients $[\nabla \varphi]$

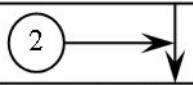

Step 9. Construction the matrix of active linear-independent constraint's gradients $\mathbf{H}[\nabla \varphi]$ with triangular structure and vector $\mathbf{H} \nabla \vec{f}$

Fig. 3.1. The flow chart for structural optimization according to the searching technique based on the gradient projection method 


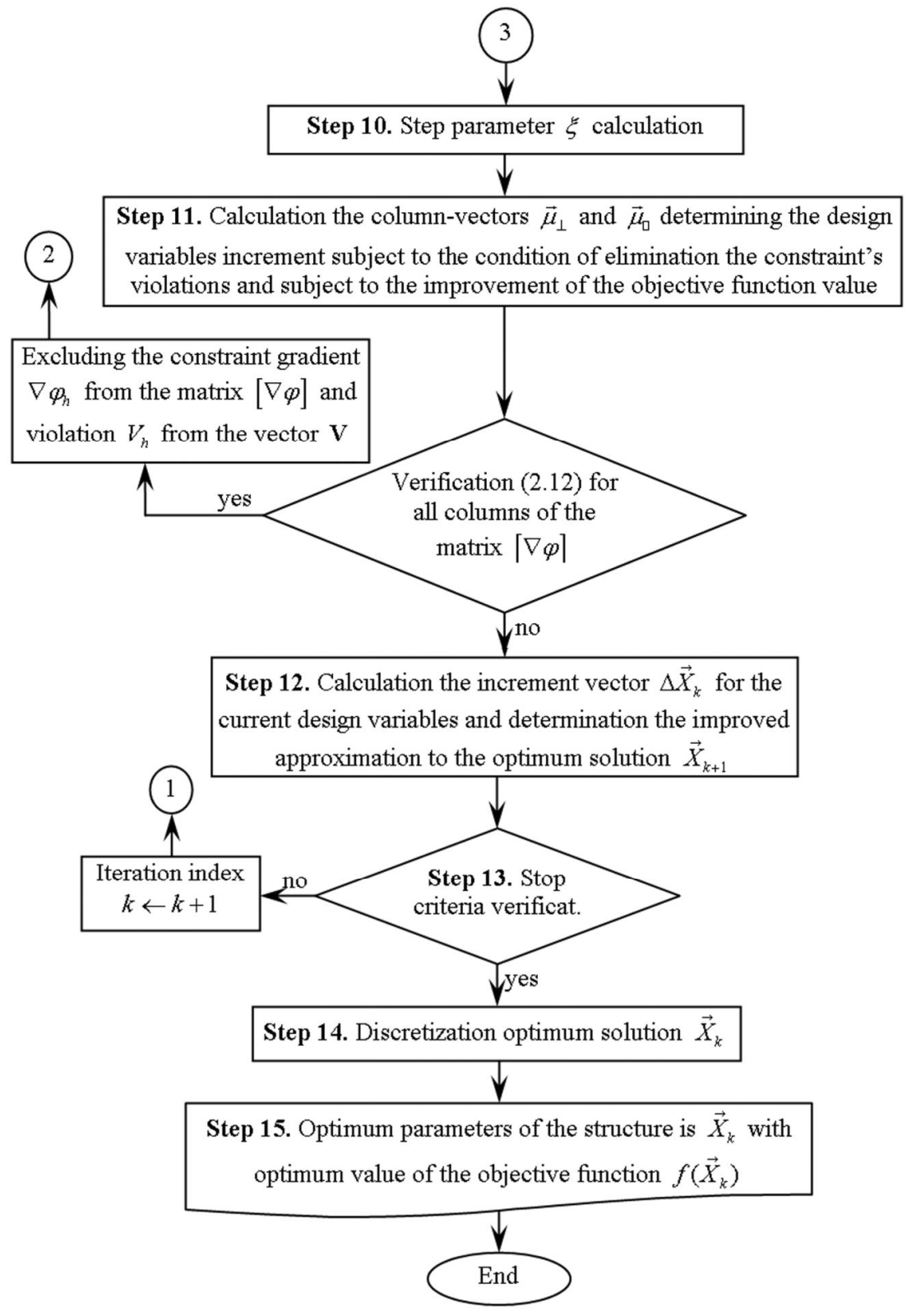

Fig. 3.1 (continuation). The flow chart for structural optimization according to the searching technique based on the gradient projection method 


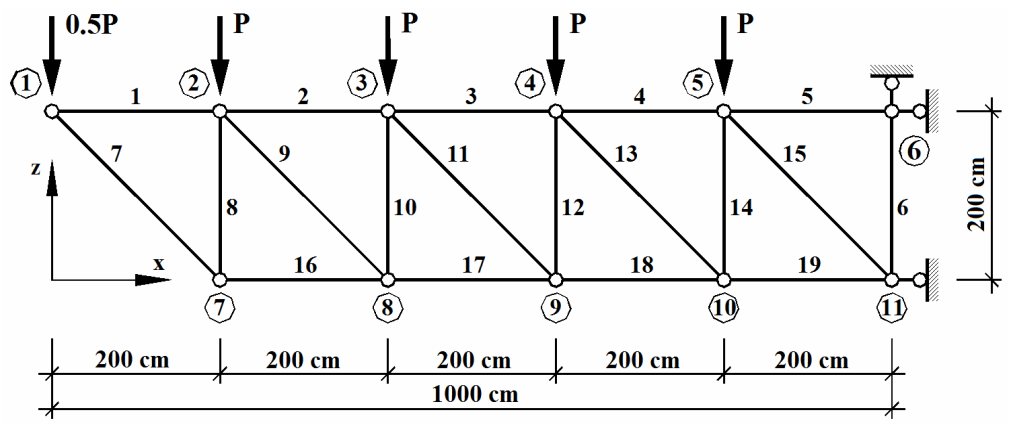

Fig. 4.1. Design scheme of the 19-bar cantilever truss

Table 4.1

Initial data for optimization of the truss

\begin{tabular}{|l|l|}
\hline Unit weight of the truss material $\rho g$ & $10^{4} \mathrm{~kg} / \mathrm{m}^{3}$ \\
\hline Modulus of elasticity $E$ & $2 \cdot 10^{4} \mathrm{kN} / \mathrm{cm}^{2}$ \\
\hline $\begin{array}{l}\text { The allowable normal stresses } \sigma_{\max } \text { in tension and } \\
\text { compression }\end{array}$ & $300 \mathrm{MPa}$ \\
\hline $\begin{array}{l}\text { The allowable displacement } \delta_{\max } \text { in the vertical direction for } \\
11^{\text {th }} \text { node }\end{array}$ & $50 \mathrm{~mm}$ \\
\hline
\end{tabular}

Truss weight minimization has been considered as the objective function. The geometry and cross-sectional optimization problem has been formulated as searching for optimum values of the vertical coordinates $z_{i}$ for all nodes of the truss lower chord, as well as for optimum value of the cross sectional area $A$ for all truss members. Variable unknown cross-sectional area $A$ for all truss members as well as unknown vertical coordinates $z_{i}$ for all truss lower chord nodes, $\vec{X}=\left(A, z_{i}\right)^{T}, i=\overline{7,11}$, were considered as design variables. The system of constraints included the normal stress constraints formulated for all truss members depending on axial forces and allowable value of the normal stresses $\sigma_{\max }$. The following displacement constraints have been also formulated for all nodes of the truss lower chord:

$$
-1-\frac{z_{i}}{z_{i}^{\text {start }}-\delta_{\max }} \leq 0 ; \frac{z_{i}}{z_{i}^{\text {start }}+H-\varepsilon}-1 \leq 0 ; \forall i=7 \ldots 11 ;
$$

where $H$ is the height of the truss panel, $H=200 \mathrm{~cm} ; \varepsilon$ is a the small positive number, $\varepsilon=10^{-7}$. The considered optimization problem dimensions were 6 design variables and 29 constraints.

Figure 4.2a presents the optimum values for vertical coordinates of the truss lower chord. The optimum cross sectional area for all truss members is $A_{\text {opt }}=4.0626 \mathrm{~cm}^{2}$. The optimum structural weight for the considered 19-bar 
cantilever truss is $G_{o p t}=139.634 \mathrm{~kg}$. There were six active constraints in the optimum point, namely normal stress constraints for the $5^{\text {th }}, 6^{\text {th }}, 17^{\text {th }}, 18^{\text {th }}, 19^{\text {th }}$ truss members, as well as displacement constraint for the $11^{\text {th }}$ truss node. The considered geometry and cross-sectional optimization problem for 19-bar cantilever truss has been solved by Czarnecki $[1,2]$. He obtained optimal structural weight $187.945 \mathrm{~kg}$.

The next geometry and cross-sectional optimization problem has been formulated as searching for optimum values of the horizontal $x_{i}$ and vertical coordinates $z_{i}$ for all nodes of the truss lower chord, as well as for optimum value of the cross sectional area $A$ for all truss members. Variable unknown cross-sectional area $A$ for all truss members, as well as unknown horizontal $x_{i}$ and vertical $z_{i}$ coordinates for all truss lower chord nodes, $\vec{X}=\left(A, x_{i}, z_{i}\right)^{T}, i=\overline{7,11}$, were considered as design variables. The system of constraints included the normal stress constraints formulated for all truss members depending on axial forces and allowable value of the normal stresses $\sigma_{\max }$. The following displacement constraints have been also formulated for all nodes of the truss lower chord:

$$
\begin{aligned}
& -1-\frac{x_{i}}{x_{i}^{\text {start }}-L+\varepsilon} \leq 0 ; \frac{z_{i}}{z_{i}^{\text {start }}+L-\varepsilon}-1 \leq 0 ; \forall i=7 \ldots 10 ; \\
& -1-\frac{z_{i}}{z_{i}^{\text {start }}-\delta_{\max }} \leq 0 ; \frac{z_{i}}{z_{i}^{\text {start }}+H-\varepsilon}-1 \leq 0 ; \forall i=7 \ldots 11 ;
\end{aligned}
$$

where $L$ is the length of the truss panel, $L=200 \mathrm{~cm}$. The considered optimization problem dimensions were 10 design variables and 37 constraints.

Figure $4.2 \mathrm{~b}$ presents the optimum design values for vertical and horizontal coordinates of the truss lower chord. The optimum cross sectional area for all truss members is $A_{\text {opt }}=4.0626 \mathrm{~cm}^{2}$. The optimum structural weight for the considered 19-bar cantilever truss is $G_{o p t}=131.11 \mathrm{~kg}$. There were eight active constraints in the optimum point, namely the normal stresses constraints formulated for the $2^{\text {nd }}, 3^{\text {rd }}, 4^{\text {th }}, 5^{\text {th }}, 7^{\text {th }}, 16^{\text {th }}$ and $19^{\text {th }}$ truss members, as well as displacement constraint formulated for $11^{\text {th }}$ node. The considered geometry and cross-sectional optimization problems for 19-bar cantilever truss has been solved by Czarnecki [1, 2]. He obtained optimal structural weight $178.842 \mathrm{~kg}$.

The comparison of the optimization results presented by the paper confirms the validity of the optimum solutions obtained using the proposed optimization methodology. For those design cases when the purpose function and constraints of the mathematical model are continuously differentiable functions, as well as the search space is smooth, a gradient projection method provides better optimum results comparing to the genetic algorithms. 


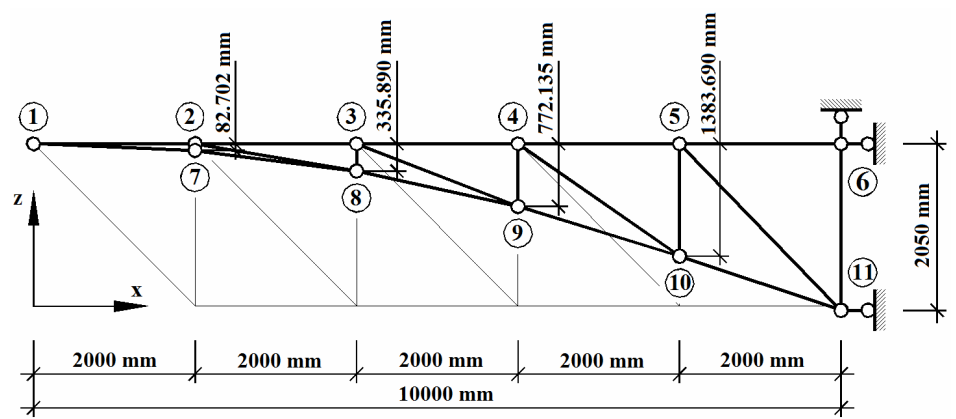

(a)
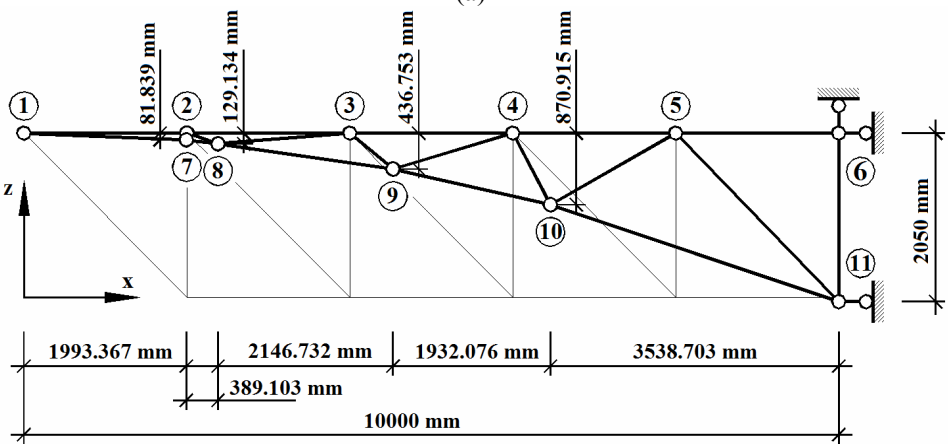

(b)

Fig. 4.2. Optimum coordinates values for all nodes of the 19-bar cantilever truss lower chord:

(a) - when vertical coordinates are considered as design variable only;

(b) - when both vertical and horizontal coordinates are considered as design variable

4.2. Cross-sectional optimization of a 41-bar roof truss. Figure 4.3 shows a 41-bar roof truss designed for the vertical loads $P=4$ ton $=39.24 \mathrm{kN}$ applied to the upper truss chord and $1.5 P=6$ ton $=58.86 \mathrm{kN}$ applied to the lower truss chord. A parametric optimization problem for the roof truss by the criterion of the material volume minimization has been solved by I-Cheng [8] using a genetic algorithm. He obtained the optimum volume $0.121689 \mathrm{~m}^{3}$ for the considered roof truss.

Initial data (see Table 4.2) and mathematical model of the 41-bar truss optimization problem are assumed as the same as described in the paper [8]. Cross-sectional areas for 21 stiffness types of the roof truss structural members are considered as the design variables, $\vec{X}=\left(A_{i}\right)^{T}, i=\overline{1,21}$ (see Figure 4.3). Cross-sectional areas of the truss members assumed to be varying discretely starting from $2 \mathrm{~cm}^{2}$ until and including $64 \mathrm{~cm}^{2}$ with step $2 \mathrm{~cm}^{2}$. The system of constraints includes normal stresses verifications for all truss members, as well as vertical displacement constraint for truss node $a$. Optimization problem dimensions are 21 design variables, 80 constraints. 


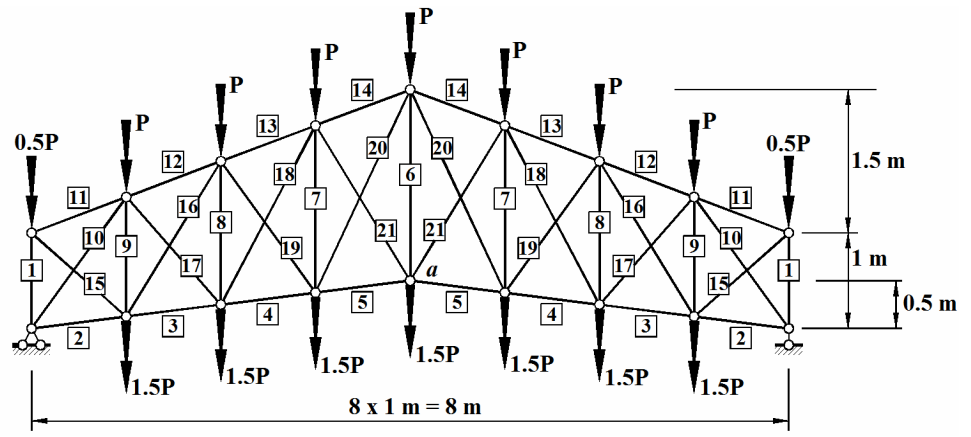

Fig. 4.3. Design scheme of the 41-bar roof truss with stiffness types numbers

Table 4.2

Initial data for optimization of the truss

\begin{tabular}{|l|l|}
\hline Modulus of elasticity $E$ & $2.06 \cdot 10^{5} \mathrm{MPa}$ \\
\hline $\begin{array}{l}\text { The allowable normal stresses } \sigma_{\max } \text { in tension and } \\
\text { compression }\end{array}$ & $\begin{array}{l}1250 \mathrm{~kg} / \mathrm{cm}^{2}= \\
12.2625 \mathrm{kN} / \mathrm{cm}^{2}\end{array}$ \\
\hline $\begin{array}{l}\text { The allowable value for the vertical displacement of the } \\
\text { roof truss node } a\end{array}$ & $6 \mathrm{~mm}$ \\
\hline
\end{tabular}

The parametric optimization problem for optimum cross-section areas of the 41-bar roof truss has been solved in the continuum space of the design variables using the improved gradient projection method described above. Table 4.3 presents the optimization result for the considered 41-bar roof truss. The optimum volume for the optimum truss solution is $V_{\text {opt }}^{\text {cont }}=0.109 \mathrm{~m}^{3}$. The optimum solution has been validated by the convergence of the optimization algorithm in the same point subjected to the different start approximations to the design variables. The optimum solution for the roof truss obtained in the continuum space of the design variables has been further discretized. The optimum volume for the optimum truss solution in discrete space of the design variables is $V_{\text {opt }}^{\text {disc }}=0.119 \mathrm{~m}^{3}$ (see Table 4.3).

The comparison of the optimization results presented by the paper confirms the validity of the optimum solutions obtained using the proposed optimization methodology. Start values of the design variables have no influence on the optimum solution of the considered non-linear optimization problem confirming in such way accuracy and validity of the optimum solutions obtained using the proposed numerical algorithm developed based on the presented gradient projection method. For those design cases when the purpose function and constraints of the mathematical model are continuously differentiable functions, as well as the search space is smooth, a gradient projection method provides better optimum results comparing to the genetic algorithms. 
Table 4.3

Optimization results for the 41-bar roof truss

\begin{tabular}{|c|c|c|}
\hline \multirow{2}{*}{$\begin{array}{l}\text { Stiffness types } \\
\text { numbers }\end{array}$} & \multicolumn{2}{|c|}{$\begin{array}{l}\text { Optimum values for cross-section areas of the truss members } \\
{\left[\mathrm{cm}^{2}\right] \text { depending on space of the design variables }}\end{array}$} \\
\hline & in continuum space & in discrete space \\
\hline 1 & 17.8208 & 18 \\
\hline 2 & 15.6555 & 16 \\
\hline 3 & 36.3758 & 38 \\
\hline 4 & 48.2494 & 50 \\
\hline 5 & 54.5526 & 56 \\
\hline 6 & 40.5101 & 42 \\
\hline 7 & 2.0000 & 2 \\
\hline 8 & 2.0000 & 2 \\
\hline 9 & 2.0000 & 2 \\
\hline 10 & 26.3752 & 28 \\
\hline 11 & 14.3494 & 16 \\
\hline 12 & 40.1982 & 42 \\
\hline 13 & 52.7656 & 54 \\
\hline 14 & 56.8969 & 58 \\
\hline 15 & 17.8746 & 18 \\
\hline 16 & 13.0426 & 14 \\
\hline 17 & 12.9413 & 14 \\
\hline 18 & 5.4713 & 6 \\
\hline 19 & 6.4781 & 8 \\
\hline 20 & 2.9064 & 4 \\
\hline 21 & 2.0000 & 2 \\
\hline Truss volume, $\mathrm{cm}^{3}$ & 0.108997 & 0.118635 \\
\hline
\end{tabular}

Conslusion. A new mathematical model for parametric optimization problems of steel structures has been proposed by the paper. The design variable vector includes geometrical parameters of the structure (node coordinates), cross-sectional dimensions of the structural members, as well as initial pre-stressing forces introduced into the specified redundant members of the structure has been formulated by the paper. The system of constraints covers load-carrying capacities constraints for all design sections of structural members subjected to all ultimate load case combinations, as well as displacements constraints for the specified nodes of the structure subjected to all serviceability load case combinations.

The method of the objective function gradient projection onto the active constraints surface with simultaneous correction of the constraints violations has been used to solve the formulated parametric optimization problem for steel structures.

A numerical algorithm for solving the formulated parametric optimization problems of steel structures based on the gradient projection method has been 
developed.

In order to estimate an efficiency of the proposed numerical algorithm, a comparison of the obtained optimization results with the results presented by the literature and widely used for testing has been performed. Good correlation of obtained results with the results of the other authors confirms the validity of the optimum solutions calculated using the proposed numerical algorithm.

It has been shown, that for those design cases when the purpose function and constraints of the mathematical model are continuously differentiable functions, as well as the search space is smooth, a gradient projection method provides better optimum results comparing to the genetic algorithms.

\section{REFERENCES}

1. Czarnecki S. Optimal structural design using a genetic algorithm // Theoretical Foundations of Civil Engineering. - 1999. - VII. - p. 201-210.

2. Czarnecki $S$. Multithreaded genetic program in truss shape optimization // Theoretical Foundations of Civil Engineering. - 2000. - VIII. - p. 556-560.

3. Crowder N. P., Denbo R. S., Mulvey J. M. Reporting computational experiments in mathematical programming // Mathematical Programming. - Vol. 15, 1978. - p. 316-329.

4. DBN V.2.6-198:2014. Steel structures. Design codes. - Kyiv: Minregion of Ukraine, 2014. - 199 p. (ukr)

5. Guljaev V.I., Bazhenov V.A., Koshkin V.L. Optimization techniques in structural mechanics (Optimization methods in structural mechanic). - Kyiv, 1988.-192 p. (rus)

6. Haug E. J., Arora J. S. Applied optimal design: mechanical and structural systems. - John Wiley \& Sons, $1979 .-520 \mathrm{p}$.

7. Huebner K. H., Dewhirst D. L., Smith D. E., Byrom T. G. The finite element method for engineers $\left(4^{\text {th }}\right.$ ed. $)-$ John Wiley \& Sons, Inc. 2001. -744 p.

8. I-Cheng $Y$. Hybrid genetic algorithms for optimization of truss structures // Computer-aided civil and infrastructure engineering. - 1999. - No. 14. - p. 199-206.

9. Koshkin V. L., Serpak I. O. Optimal design of flexible rod structural members // Strength of materials. - 1993. - No. 25. - p. 834-840. DOI: 10.1007/BF00780267

10. Kuci E., Henrotte F., Duysinx P., Geuzaine C. Design sensitivity analysis for shape optimization based on the Lie derivative // Computer methods in applied mechanics and engineering. - Vol. 317, 2017. - p. 702-722. DOI: 10.1016/i.cma.2016.12.036

11. Peleshko I., Yurchenko $V$. An optimum structural computer-aided design using update gradient method // Proceedings of the $8^{\text {th }}$ International Conference "Modern Building Materials, Structures and Techniques". - Faculty of Civil Engineering, Vilnius Gediminas Technical University, 2004. p. $860-865$.

12. Peleshko I., Yurchenko V. An improved gradient-based method to solve parametric optimisation problems of the bar structures // Strength of Materials and Theory of Structures: Scientific-andtechnical collected articles. - Kyiv: KNUBA, 2020. - Issue 104. (accepted to publication)

13. Permyakov V. O., Yurchenko V.V., Peleshko I. D. An optimum structural computer-aided design using hybrid genetic algorithm // Proceeding of the International Conference "Progress in Steel, Composite and Aluminium Structures". - Taylor \& Francis Group, London, 2006. - p. 819-826.

14. Perelmuter A., Yurchenko $V$. Parametric optimization of steel shell towers of high-power wind turbines // Procedia Engineering. - No.57, 2013. - p.895-905. DOI: 10.1016/ j.proeng.2013.04.114.

15. Reklaitis G. V., Ravindran A., Ragsdell K. M. Engineering optimization. Methods and applications. Wiley, 2006. $-688 \mathrm{p}$.

16. Yurchenko V., Peleshko I., Beliaev N. Parametric optimization of steel truss with hollow structural members based on update gradient method // Proceedings of International Conference "Design, Fabrication and Economy of Metal Structures". - Springer Berlin Heidelberg, 2013. - p. 103-109. DOI: $10.1007 / 978-3-642-36691-816$

17. Wilkinson J. H., Reinsch C. Handbook for Automatic Computation. Volume II: Linear Algebra. Heidelberg New York Springer-Verlag Berlin, 1971.-441 p. DOI: 10.1137/1014116. 
Юрченко В. В., Пелешко І. Д.

\section{ПАРАМЕТРИЧНА ОПТИМІЗАЦІЯ МЕТАЛЕВИХ СТЕРЖНЕВИХ КОНСТРУКЦІЙ НА ОСНОВІ МЕТОДУ ПРОЕКЦІЇ ГРАДІЕНТА}

Метою дослідження $\epsilon$ розробка чисельної методики для розв'язку задачі параметричної оптимізації сталевих стержневих конструкцій при орієнтації на ії програмну реалізацію у системі автоматизованого проектування. У статті запропонована нова математична модель для розв'язку задачі параметричної оптимізації металевих стержневих конструкцій. Вектор змінних проектування охоплює параметри геометричної схеми конструкції (координати вузлів), розміри поперечних перерізів несучих елементів конструкції, а також зусилля попереднього напруження, що вводяться у визначені зайві в'язі конструкції. У систему обмежень залучені обмеження несучої здатності, сформульовані для усіх розрахункових перерізів несучих елементів металевої стержневої конструкції, що підлягає дії розрахункових комбінацій навантажень першого граничного стану, а також обмеження переміщень, сформульовані для визначених вузлів стержневої системи, що підлягає дії розрахункових комбінацій навантажень другого граничного стану. Для розв'язку поставленої задачі параметричної оптимізації використаний метод проекції градієнта функції мети на поверхню активних обмежень 3 одночасною ліквідацією нев'язок в порушених обмеженнях. У статті також запропонований чисельний алгоритм для розв'язку поставленої задачі параметричної оптимізації сталевих конструкцій. Результати оптимізаційних розрахунків стальних ферм, які представлені у статті, підтвердили достовірність оптимальних рішень, отриманих з використанням запропонованої чисельної методики.

Ключові слова: параметрична оптимізація, сталеві стержневі конструкції, нелінійне програмування, обмеження стійкості, зусилля попереднього напруження, координати вузлів, градієнтний метод, метод скінчених елементів, чисельний алгоритм.

Yurchenko V. V., Peleshko I. D.

\section{PARAMETRIC OPTIMIZATION OF STEEL STRUCTURES BASED ON GRADIENT PROJECTION METHOD}

The main research goal is the development of a numerical methodology for solving parametric optimization problems of steel structures with orientation on software implementation in a computer-aided design system. The paper has proposed a new mathematical model for parametric optimization problems of steel structures. The design variable vector includes geometrical parameters of the structure (node coordinates), cross-sectional dimensions of the structural members, as well as initial pre-stressing forces introduced into the specified redundant members of the structure. The system of constraints covers load-carrying capacities constraints formulated for all design sections of structural members of the steel structure subjected to all ultimate load case combinations. The displacements constraints formulated for the specified nodes of the steel structure subjected to all serviceability load case combinations have been also included into the system of constraints. The method of the objective function gradient projection onto the active constraints surface with simultaneous correction of the constraints violations has been used for solving the parametric optimization problem. A numerical algorithm for solving the formulated parametric optimization problems of steel structures has been developed in the paper. The comparison of the optimization results of truss structures presented by the paper confirms the validity of the optimum solutions obtained using the proposed numerical methodology.

Keywords: parametric optimization, steel structures, nonlinear programming, buckling constraints, pre-stressing forces, node coordinates, gradient projection method, finite element analysis, numerical algorithm.

\section{Юрченко В. В., Пелешко И. Д.}

\section{ПАРАМЕТРИЧЕСКАЯ ОПТИМИЗАЦИЯ МЕТАЛЛИЧЕСКИХ СТЕРЖНЕВЫХ КОНСТРУКЦИЙ НА ОСНОВЕ МЕТОДА ПРОЕКЦИИ ГРАДИЕНТА}

Целью исследования является разработка численной методики для решения задач параметрической оптимизации стальных конструкций при ориентации на ее программную реализацию в системе автоматизированного проектирования. В статье предложена новая математическая модель для решения задач параметрической оптимизации стальных конструкций. Вектор переменных проектирования охватывает параметры геометрической 
схемы конструкции (координаты узлов), размеры поперечных сечений несущих элементов конструкций, а также усилия предварительного натяжения, вводимые в указанные лишние связи конструкции. В систему ограничений включены ограничения несущей способности, сформулированные для всех расчетных сечений несущих элементов стальной стержневой конструкции, подверженной действию расчетных комбинаций нагрузок первого предельного состояния. Ограничения перемещений, сформулированные для определенных узлов стержневой системы, подверженной действию расчетных комбинаций нагрузок второго предельного состояния, также включены в систему ограничений. Для решения поставленной задачи параметрической оптимизации был использован метод проекции градиента функции цели на поверхность активных ограничений с одновременной ликвидацией невязок в ограничениях. В статье также предложен численный алгоритм для решения поставленной задачи параметрической оптимизации стальных конструкций. Результаты оптимизационных расчетов стальных ферм, представленные в статье, подтвердили достоверность оптимальных решений, получаемых с использованием предложенной численной методики.

Ключевые слова: параметрическая оптимизация, стальные стержневые конструкции, нелинейное программирование, ограничения устойчивости, усилия предварительного натяжения, координаты узлов, градиентный метод, метод конечных элементов, численный алгоритм.

\section{УДК $624.04,519.853$}

Юрченко В. В., Пелешко I. Д. Параметрична оптимізація металевих стержневих конструкцій на основі методу проекції градіснта // Опір матеріалів і теорія споруд: наук.тех. збірн. - К.: КНУБА, 2020. - Вип. 105. - С. 192-220.

У статті запропонована нова математична модель для розв'язку задачі параметричної оптимізачії металевих стержневих конструкиій. Вектор змінних проектування охоплює параметри геометричної схеми конструкції (координати вузлів), розміри поперечних перерізів несучих елементів конструкиіі, а також зусилля попереднього напруження, щчо вводяться у визначені зайві в'язі конструкції. У систему обмежень залучені обмеження несучої здатності, сформульовані для усіх розрахункових перерізів несучих елементів металевої стержневої конструкції, щзо підляає дії розрахункових комбінацій навантажень першого граничного стану, а також обмеження переміщень, сформульовані для визначених вузлів стержневої системи, щуо підлягає дії розрахункових комбінацій навантажень другого граничного стану. Для розв'язку поставленої задачі параметричної оптимізації використаний метод проекції градієнта функиї мети на поверхню активних обмежень з одночасною ліквідацією нев'язок в порушених обмеженнях. У статті також запропонований чисельний алгоритм для розв'язку поставленої задачі параметричної оптимізації сталевих конструкцій.

Іл. 6. Табл. 3. Бібліог. 17 назв.

\section{УДК 624.04, 519.853}

Yurchenko $V$. V., Peleshko I. D. Parametric optimization of steel structures based on gradient projection method // Strength of Materials and Theory of Structures: Scientific-and-technical collected articles - Kyiv: KNUBA, 2020. - Issue 105. - P. 192-220.

The paper has proposed a new mathematical model for parametric optimization problems of steel structures. The design variable vector includes geometrical parameters of the structure (node coordinates), cross-sectional dimensions of the structural members, as well as initial pre-stressing forces introduced into the specified redundant members of the structure. The system of constraints covers load-carrying capacities constraints formulated for all design sections of structural members of the steel structure subjected to all ultimate load case combinations. The displacements constraints formulated for the specified nodes of the steel structure subjected to all serviceability load case combinations have been also included into the system of constraints. The method of the objective function gradient projection onto the active constraints surface with simultaneous correction of the constraints violations has been used for solving the parametric optimization problem. A numerical algorithm for solving the formulated parametric optimization problems of steel structures has been developed in the paper.

Figs. 6. Tabs. 3. Refs. 17. 
УДК $624.04,519.853$

Юрченко В.В., Пелешко И. Д. Параметрическая оптимизация металлических стержневых конструкций на основе метода проекции градиента // Сопротивление материалов и теория сооружений: науч.- тех. сборн. - К.: КНУСА, 2020. - Вып. 105. C. $192-220$.

В статье предложена новая математическая модель для решения задач параметрической оптимизации стальных конструкций. Вектор переменных проектирования охватывает параметры геометрической схемы конструкиии (координаты узлов), размеры поперечных сечений несущих элементов конструкиий, а также усилия предварительного натяжения, вводимые в указанные лишние связи конструкиии. В систему ограничений включены ограничения несущей способности, сформулированные для всех расчетных сечений несущих элементов стальной стержневой конструкции, подверженной действию расчетных комбинаций нагрузок первого предельного состояния, а также ограничения перемещений, сформулированные для определенных узлов стержневой системы, подверженной действию расчетных комбинаций нагрузок второго предельного состояния. Для решения поставленной задачи параметрической оптимизации использован метод проекции градиента функции цели на поверхность активных ограничений с одновременной ликвидацией невязок в ограничениях. $B$ статье предложен численный алгоритм для решения поставленной задачи параметрической оптимизации стальных конструкиий.

Ил. 6. Табл. 3. Библиог. 17 назв.

Автор: доктор технічних наук, професор кафедри металевих та дерев'яних конструкиій Юрченко Віталіна Віталіївна

Адреса робоча: 03680 Украӥна, м. Київ, Повітрофлотський пр. 31, Київський начіональний університет будівниитва і архітектури

Робочий тел.: +38(044)249-71-91

Мобільний тел..: +38(063)89-26-491

E-mail: vitalina@scadsoft.com

SCOPUS ID: 25637856200

ORCID ID: https://orcid.org/0000-0003-4513-809X

Автор: кандидат технічних наук, доцент кафедри будівельного виробнищтва

Пелешко Іван Дмитрович

Адреса робоча: 79013 Україна, м. Львів, вул.. Ст. Бандери 12, Національний університет «Львівська політехніка»

Робочий тел.: +38 (032) 258-25-41

Мобільний тел..: +38(098) 41-57-517

E-mail: ipeleshko@polynet.lviv.ua

SCOPUS ID: 25637832500

ORCID ID: https://orcid.org/0000-0001-7028-9653 